\title{
Relationship between Maternal and Children Body Mass Index in four Educational Systems in Hidalgo, Mexico
}

\author{
Melissa García Meraz ${ }^{a}$, Rebeca María Elena Guzmán Saldaña ${ }^{b}$, \\ Guadalupe López-Rodríguez , Marcos Galván ${ }^{\mathrm{b}, *}$

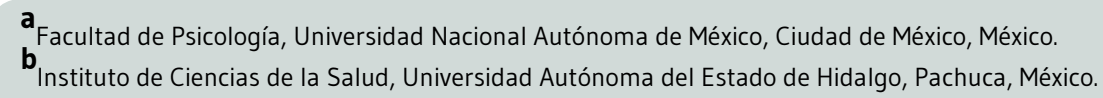

Editor Asignado: Eduard Baladia. Comité Editorial de la Revista Española de Nutrición Humana y Dietética. Pamplona, España.

Received: 09/02/2019; accepted: 28/10/2019; published: 18/12/2019.

\section{KEYWORDS}

Body Mass Index;

Ethnic Groups;

Child;

Mother-Child

Relations.
Relationship between Maternal and Children Body Mass Index in four Educational Systems in Hidalgo, Mexico

\section{ABSTRACT}

Introduction: While the prevalence of overweight and obesity is pervasive in adults and children in Mexico, differences and relationships among children and their mothers from different ethnic groups, educational systems, and environmental settings in Mexico is understudied. Objective: The present study tested the relationship between Maternal Body Mass Index (MBMI) and Children's Z-score Body Mass Index for Age (ZBFA) from indigenous, private, public and CONAFE (community schools in marginalized rural areas) schools representing four distinct educational systems in Hidalgo, Mexico.

Material and Methods: A survey-type study was carried out in a random sample of school children and their mothers. The weight and height of the children and their mothers was evaluated with standardize anthropometric techniques. Mothers' and children's scores were evaluated following the recommendations by the World Health Organization (WHO).

Results: Prevalence of overweight was very high in mothers (55.8\%), without significant differences in MBMI across the four different educational systems. Children from private schools showed higher Body Mass Index, being the girls with the highest scores. Our initial model only included MBMI and Children's ZBFA, this relationship provided us with a model that explained only $7 \%$ of the variance. However, when school type was added as covariate in models for boys and girls, the explained variance increased ( $17 \%$ and $33 \%$ respectively).

Conclusions: It was found evidence of a low relationship between Maternal Body Mass Index and Child Body Mass Index. This relationship was stronger when the type of school was added as a covariate. The evidence revealed differences between the environment of rural and urban schools, between mestizo populations and indigenous groups. 
Relación entre el Índice de Masa Corporal Materno y de sus Hijos en cuatro Sistemas Educativos de Hidalgo, México

\section{PLABRAS CLAVE}

Índice de Masa

Corporal;

Grupos Étnicos;

Niño;

Relaciones

Madre-Hijo.

\section{RESUMEN}

Introducción: Si bien la prevalencia del sobrepeso y la obesidad es una epidemia en adultos y niños en México, las diferencias y las relaciones entre los niños y sus madres de diferentes grupos étnicos y sistemas educativos en México han sido poco estudiadas. Objetivo: El presente estudio probó la relación entre el Índice de Masa Corporal Materno (IMCM) y los puntajes Z del Índice de Masa Corporal de sus hijos (ZIMC) de estudiantes de escuelas indígenas, privadas, públicas y CONAFE (escuelas comunitarias rurales marginadas) en el estado de Hidalgo, México.

Material y Métodos: Se realizó un estudio tipo encuesta en una muestra aleatoria de niños en edad escolar y sus madres. El peso y estatura de niños y sus madres se evaluaron con técnicas antropométricas estandarizadas de acuerdo con protocolos de la Organización Mundial de la Salud (OMS).

Resultados: La prevalencia de sobrepeso fue muy alta en las madres $(55,8 \%)$, sin una diferencia significativa en el IMCM por tipo de escuela. Niños que asistían a escuelas privadas tenían un ZIMC más alto, y fue mayor en el caso de las niñas. El IMCM se relacionó con el ZIMC de los niños (7\% varianza explicada), cuando agregamos el tipo de escuela como covariable en modelos por sexo, el porcentaje aumentó (17\% para niños y 33\% para niñas).

Conclusiones: Se encontró evidencia de una baja relación entre el índice de masa corporal materno y el índice de masa corporal infantil. Esta relación fue más fuerte cuando se agregó el tipo de escuela como covariable, lo que reveló diferencias entre el ambiente de las escuelas rurales y urbanas, entre las poblaciones mestizas y los grupos indígenas.

\section{CITATION}

García Meraz M, Guzmán Saldaña RME, López-Rodríguez G, Galván M. Relationship between Maternal and Children Body Mass Index in four Educational Systems in Hidalgo, Mexico. Rev Esp Nutr Hum Diet. 2019; 23(4): 252-60. doi: 10.14306/renhyd.23.4.753

\section{INTRODUCTION}

Worldwide data indicate that there are more than 42 million children under 5 years old with overweight in $2013^{1}$. In Mexico, the ENSANUT (National Survey on Health and Nutrition) has revealed that in 2016, three out of ten boys and girls (ages between 5-11 years old) have overweight or obesity (33.2\%). In adults (older than 20 years old), the combined prevalence of overweight and obesity is $72.5 \%$. The most relevant increase is in adult women $(75.6 \%$ with respect to 2012), being women in rural environment with the highest increase (8.4\%) compared to women in urban environment $(1.6 \%)^{2}$. These differences have been reported in Mexico by sex, and between rural and urban populations; however, there are no data in rural environment according to ethnicity. The Body Mass Index (BMI) is an indicator frequently used to evaluate the prevalence of overweight and obesity; however, there is now plentiful evidence to support the hypothesis that BMI is not equivalent in different populations across different ethnicities and sex ${ }^{3}$. Valdhuis, te Poel, Pepping, Konijn, \& Spekman have showed that overweight and obesity is higher among children of some non-Western ethnic minorities than among their Caucasian counterparts in Dutch population ${ }^{4}$. Some other disparities can be showed between Hispanic, African-American and White boys and girls in the United States. Some of these differences can be explained by differences in birth weight and family characteristics, including the perception of parents about safety in neighborhoods ${ }^{5}$. O'Hara \& HaynesMaslow have pointed out that Hispanic male children and low-income Hispanic children reported a positive association between $\mathrm{BMI}$ and vending machine availability compared to other ethnic groups ${ }^{6}$. Similarly, Maternal Body Mass Index (MBMI) can be associated to child nutritional status. Tigga \& Sen indicate a strong genetic component between mothers 
and their children anthropometry?. Maternal nutritional status is strongly related to children nutritional status and their BMI during the whole life ${ }^{8,9}$. Other factors can influence in the Children Body Mass Index (CBMI) such as: birth weight, television viewing hours, fast food, physical activity, maternal smoking during the first year of life, maternal and paternal smoking, maternal weight, skipping breakfast during pregnancy, early life exposures to antibiotics and other drugs, poverty, low income, birth weight, low levels of education, maternal health, health behaviors during pregnancy, breastfeeding duration, and child-mother socioeconomic status and poor access to health and educational services ${ }^{1,10-12}$.

Mexico has a diversity of indigenous groups and lowincome populations in rural areas that have specific scholar programs for children and adolescents. For this study, four distinct elementary school programs (for children between 6 and 12 years old) were identified. Broadly, there are school programs for children in urban and rural environments that are completely secular and public. Alternatively, a child can assist to private school; these schools involve several costs depending on the courses, quality and geography, they are not necessarily secular and are not completely regulated by the state ${ }^{13}$. A third case of elementary schools are the CONAFE schools (National Council for Educational Development). These schools promote and provide a different and specific educational attention to rural population, who do not have the benefits of urban social development ${ }^{14}$. Finally, the fourth case of elementary school is part of the public system but with the particularity of being specific for indigenous communities in Mexico.

Given the differences between urban and rural populations and overall indigenous population, the aim of this study was to test the relation between Maternal Body Mass Index (MBMI) and Z-score Body Mass Index for Age (ZBFA) and the differences in mothers and their children (boys and girls) in four different school systems (these systems involved at least three different groups in Mexico: Indigenous, Rural, and Urban populations) in order to know differences between children from different populations and the relationship with their mothers.

\section{MATERIAL AND MEthods}

\section{Participants}

The present study was carried out among children and their mothers from Hidalgo State, Mexico. Hidalgo is one of the 32 political and economic administrations in Mexico, the state is divided into 84 municipalities and a Capital City named Pachuca de Soto. The most representative native cultures are the Nahuatl and Otomi cultures. The geographic area is of roughly 20,813 square $\mathrm{km}$ and total population are around 2.665 million, of which approximately $13 \%$ corresponds to school-age population ${ }^{15}$

A survey-type study was carried out in a random sample of school age children and their mothers, who were part of the project "Nutritional Profile of School Children from Hidalgo 2010 (PENUTEH)". The participants were selected using a stratified random sampling method in all the State, the main reference was the school and the four different elementary school systems. The names of all these students from $1^{\text {st }}, 3$ rd and $6^{\text {th }}$ year were registered, and it was used a representative sample of 917 school children and their mothers. Subsequently, the selected children and their corresponding mothers were identified and both were measured. After that, a balanced ANOVA model was made with the same quantity of children in each educational system. Power and sample size of a statistical ANOVA test (0.80) was calculated in order to avoid the likelihood of Type II error. With a model of gender $2 *$ and school type 4, 10 participants per group are required. In our case, 30 participants were recruited (60 mothers and children from a private school, 60 mothers and children from a public school, 60 mothers and children from an indigenous school, and 60 mothers and children from CONAFE Schools). In order to estimate effect size, eta squared and d Cohen were calculated.

\section{Anthropometric measurements recorded}

The weight (scale SECA ${ }^{\circledR}$ model 813 , precision=100g) and height (portable model SECA ${ }^{\circledR}$ model 206 , precision $=0,1 \mathrm{~cm}$ ) of the children and their mothers were evaluated by previously standardized nutritionists who used conventional anthropometric techniques. The values of $\mathrm{Z}$-score heightfor-age (ZHFA) and Z-score for Body Mass Index for Age (ZBFA), Children Body Mass Index (CBMI) were calculated by using the WHO child growth reference value in the $\mathrm{R}$ macro package ${ }^{16}$. The Maternal Body Mass Index (MBMI) and classification were calculated and assessed following international cutoff point proposed by the World Health Organization $(\mathrm{WHO})^{17}$.

\section{Statistical Analysis}

A two-way ANOVA model analysis $(4 * 2)$ was applied in order to find statistical differences between main effects and interactions among ZBFA by types of Mexican Schools and children sex. Data were tested for normality and homogeneity 
of variance. Data had a normal distribution $p=0.093$ tested with Shapiro-Wilk test. Homogeneity of variance was rejected. It was decided to adjust data significance with Bonferroni test effects for nonhomogeneity of variance. One-way ANOVA model analysis with MBMI was conducted in order to find differences between the four different school types. Simple linear regression was conducted with ZBFA as criterion variable and MBMI as predictor variable. Finally, an Analysis of Covariance was conducted as General Linear Model to assess the association of MBMI (predictor) on children's $Z$-scores (criterion) with type of school as covariate in two different models, one for boys, and one for girls.

The data was statistically analyzed using $R$ program 3.4.2 version as a free software environment for statistical computing and graphics, as well as R Studio 1.1.453.

\section{Ethical considerations}

This research is part of the project Nutritional Profile of School Children from Hidalgo 2010 (PENUTEH) approved by the Ethics Committee of the School of Health Sciences at the Universidad Autónoma del Estado de Hidalgo, which is governed by medical research principles when research involves human subjects (Declaration of Helsinki). In all cases there is an informed consent signed by the mothers and the child's assent was requested to make the assessments.

\section{$\longrightarrow$ \\ RESULTS}

The overall mean and standard deviation of mothers and their children was summarized in Table 1.

\section{Prevalence of Different Grades of Nutrition among Mothers based on BMI}

The prevalence of overweight, obesity and morbid obesity was very high, more than half, $55.8 \%(n=134)$. It is important to point out that $42.5 \%(n=102)$ of mothers are within the normal range (Table 2 ).

The differences between MBMI in mothers with children in the four educational systems, were tested; data indicate that there is not a significant difference $\left(F_{(3,232)}=1.112, p=0.345\right.$, $\eta^{2}=0.014$ ).

\section{Children Body Mass Index: Differences between Sex and School type}

There is no significant main effect of sex (boys and girls) $\left(F_{(1,232)}=2.325, p=0.128, \eta^{2}=0.010\right)$. There is a significant main effect of school type $\left(F_{(3,232)}=16.282, p=0.000, \eta^{2}=0.174\right)$. Post hoc analysis with Bonferroni adjustment indicates differences between the following groups: Children studying

Table 1. Descriptive statistics of the age of mothers and children and anthropometric variables.

Variable

Mothers' variables

Age (years)

Height (cm)

Weight $(\mathrm{kg})$

MBMI $\left(\mathrm{kg} / \mathrm{m}^{2}\right)$

Mothers' waist (cm)

Children's variables

Age (years)

Height (cm)

Weight (kg)

CBMI $\left(\mathrm{kg} / \mathrm{m}^{2}\right)$

ZHFA (Z-score)

ZWFA (Z-score)

ZBFA (Z-score)

\section{$\mathbf{N}$}

237

240

240

240

238

240

240

240

240

240

176

240
Mean SD

$34.06 \pm 6.39$

$151.87 \pm 6.27$

$60.30 \pm 11.56$

$26.06 \pm 4.26$

$83.87 \pm 9.90$

Girls

$8.86 \pm 2.01$

$127.16 \pm 13.84$

$27.98 \pm 9.54$

$16.79 \pm 2.62$

$-0.8132 \pm 1.01$

$-0.4809 \pm 1.16$

$0.0908 \pm 1.10$
Boys

$8.67 \pm 2.06$

$126.66 \pm 12.66$

$27.89 \pm 8.82$

$16.95 \pm 2.50$

$-0.7280 \pm 1.09$

$-0.2653 \pm 1.32$

$0.2899 \pm .13$ 
Table 2. Mother Body Mass Index (MBMI) and classification.

\begin{tabular}{l|c|c} 
Classification & MBMl kg/m & N 240 (\%) \\
\hline Severe thinness & $\leq 15.99$ & 0 \\
\hline Moderate thinness & $16.00-16.99$ & 0 \\
\hline Mild thinness & $17.00-18.49$ & $4(1.7 \%)$ \\
\hline Normal range & $18.50-24.99$ & $102(42.5 \%)$ \\
\hline Overweight & $25.00-29.99$ & $92(38.3 \%)$ \\
\hline Obesity & $30.00-39.99$ & $41(17.1 \%)$ \\
\hline Morbid Obesity & $\geq 40.00$ & $1(0.4 \%)$
\end{tabular}

in private schools have higher scores $(0.861 \pm 1.17)$ than children in public $(0.335 \pm 1.06)$, indigenous $(-0.340 \pm 0.906)$ and rural schools $(-0.095 \pm 0.943)$.

There is a significant interaction effect between school type and sex $\left(F_{(3,232)}=3.255, p=0.022, \eta^{2}=0.040\right)$. Post hoc analysis with Bonferroni adjustment indicates differences between the following groups: Girls studying in a Private school have higher scores $(1.034 \pm 0.903)$ than girls in other educational systems (Public school $-0.026 \pm 1.061, p=0.031$; Rural school
$-0.308 \pm 1.022, p<0.000$ and Indigenous School $-0.336 \pm 0.831$, $\mathrm{p}<0.000)$. Also, girls studying in a Public school have a higher ZBMA than boys studying in Rural (0.119 \pm 0.819$)$, $p=0.002$ and indigenous schools $(-0.342 \pm 0.990), p<0.000$. In the case of boys, those studying in Private schools (0.687 \pm 1.392$)$ have a higher ZBMA than boys in indigenous schools $(-0.342 \pm 0.990), p=0.010$, girls from an Indigenous school $(-0.336 \pm 0.831), p=0.002$, and girls from a rural school $(-0.308 \pm 1.022), p=0.004$ (Figure 1 ).

Figure 1. Plot of the effects of the interaction between sex and school type by Z-score for Body Mass Index for Age (ZBFA).

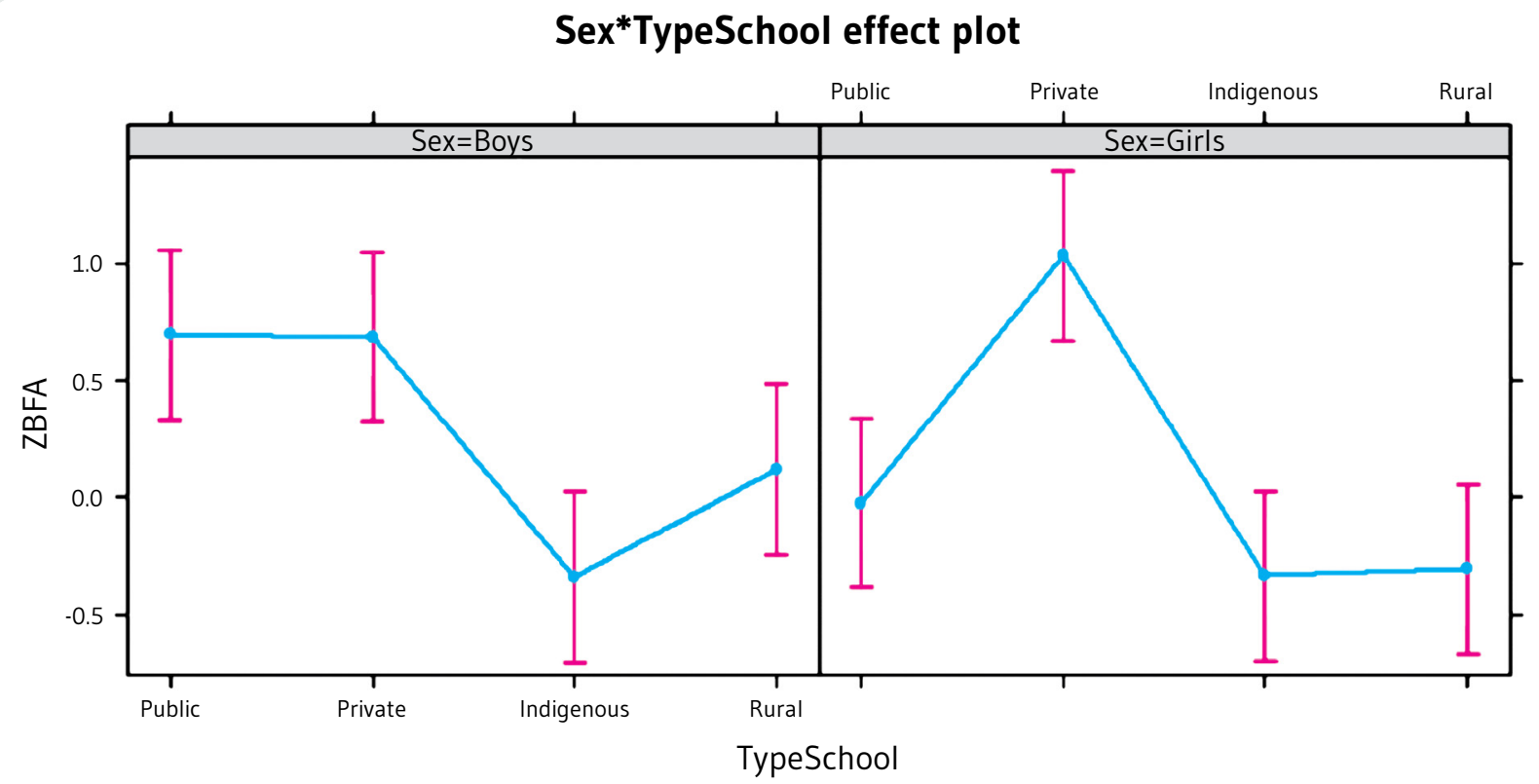




\section{Relationship between MBMI and ZBFA}

A simple linear regression was used in order to test the relationship between MBMI (predictor variable) and ZBFA (criterion variable). With this model a significant proportion of variance was explained $7.3 \%, R^{2}=0.073$, adjusted $R^{2}=0.069$, $F_{(1,238)}=18.93, p=0.000$ (Figure 2).

In fact, that two-way ANOVA model showed differences between school type and sex. It was decided to conduct a covariate analysis with ZBFA as criterion variable, MBMI as Predictor and the School type as a covariate in the sample, one model for girls and one model for boys.

\section{Boys Model: MBMI and ZBFA for School Type}

With the MBMI and the School type as moderator, a significant proportion of variance in ZBFA was accounted for $17 \%$, $R^{2}=0.172$, adjusted $R^{2}=0.143, F_{(4,115)}=6, p=0.000$. A histogram of residuals from a linear model shows that the distribution of these residuals was approximately normal. Boys from public and private schools have a similar pattern with higher scores of ZBFA (Figure 3).

\section{Girls Model: MBMI and ZBFA for School Type}

In the girls model the results were: $R^{2}=0.329$, adjusted $R^{2}=0.306, F_{(4,115)}=14.12, p=0.000$. The model explained $33 \%$ of the variance; double from the boy's model. Residuals were approximately normal. Girls studying in the private school were different from the rest (Figure 4).

\section{Discussion}

The aim of this study was to explore the association between MBMI and ZBFA among children from different school systems. As a first result, differences by type of school were found: children from a private school have higher scores than the other three groups and even when there is no difference between children sex, interaction shows differences between girls from a private school compared to the rest of the girls. MBMI influenced the ZBFA but, when the school was added as a covariate, the explained variance increased from $7.3 \%$ to $14 \%$ in boys and $33 \%$ in girls. The relationship motherdaughter was clearer than mother-son relationship.

The results of the current study are in line with findings from other studies. Previous research also found that MBMI has an important influence over ZBFA ${ }^{3,5}$, nevertheless, is not equivalent in populations across different ethnicities ${ }^{6}$. Even when MBMI can be highly associated with ZBFA, ethnicity can have differences related to other socioeconomic

Figure 2. Simple linear regression for the relationship between MBMI and ZBFA.

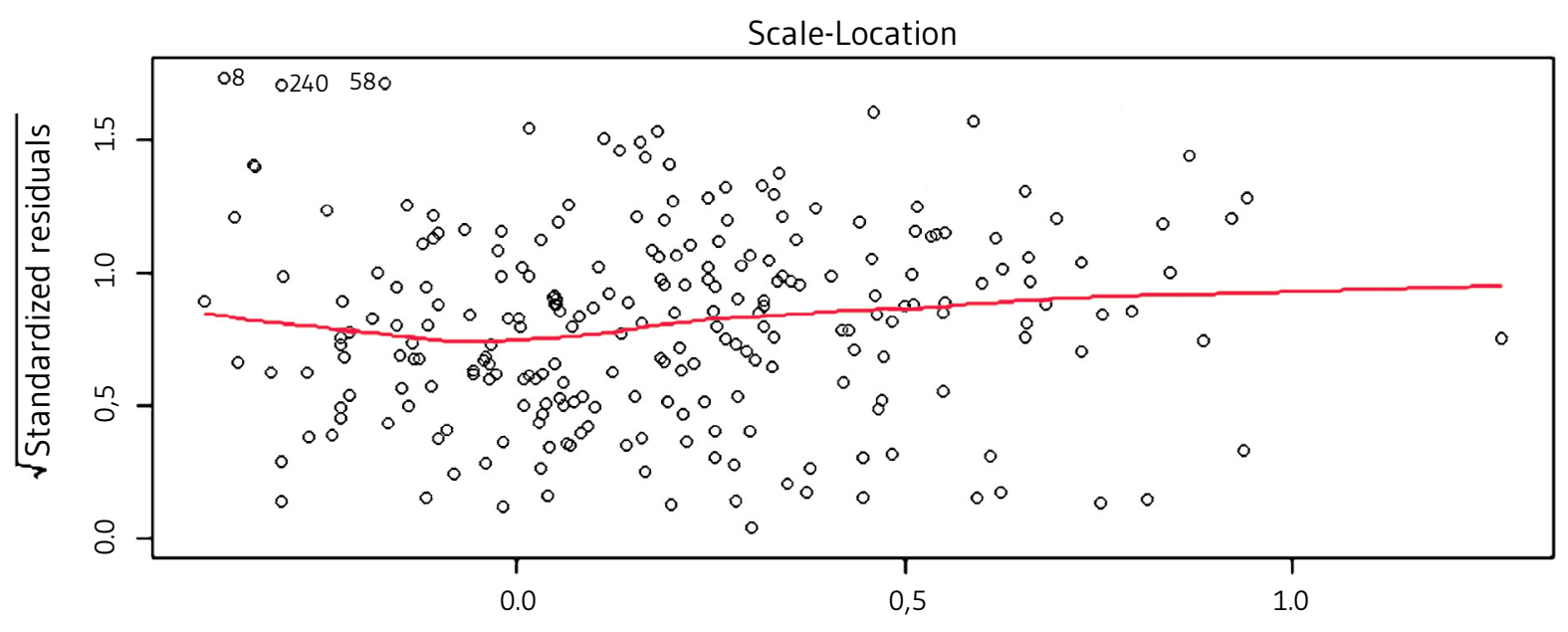

Fitted values

Im (ZBFA MBMI) 
Figure 3. Best fit lines for ZBFA in children predicted for MBMI and mediated by the school type in boys.

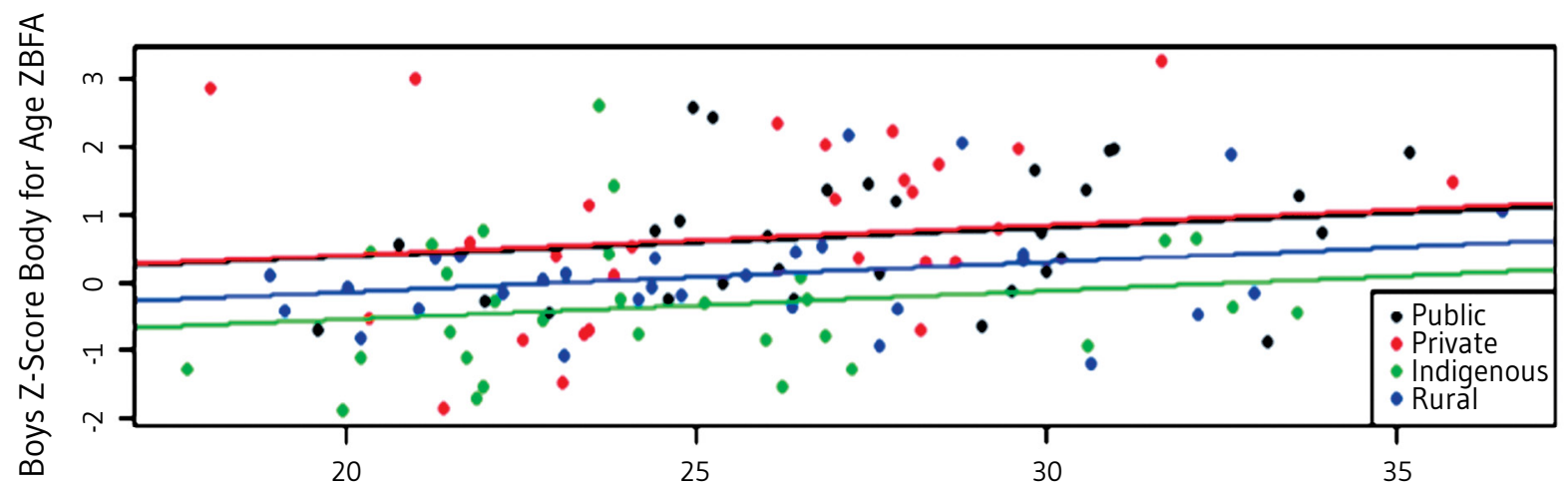

Maternal Body Mass Index MBMI

Figure 4. Best fit lines for ZBFA predicted for MBMI and mediated by the school type in girls.
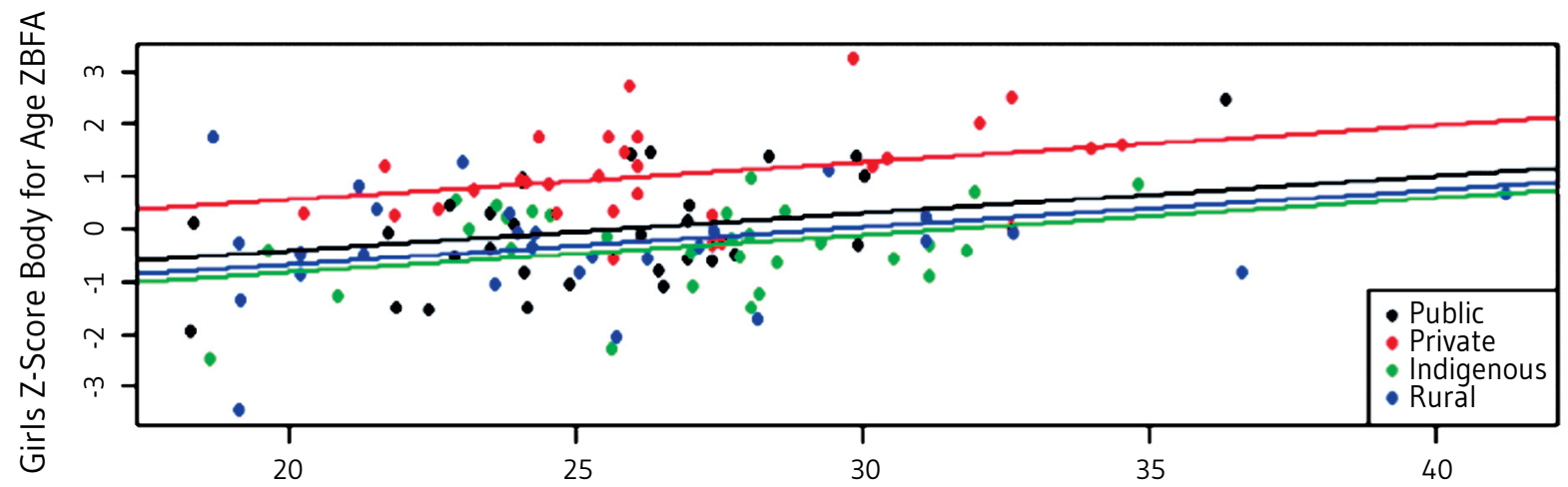

Maternal Body Mass Index MBMI

characteristics, these differences can be related to economical rate, income, educational level, access to nutritious and diverse food, poor access to health and educational services ${ }^{1,10-12}$. These disparities should be taken into account when MBMI and ZBFA relationship is assessed. Furthermore, these differences should be analyzed in order to identify a health public agenda that pointed out the diversity of this relationship, and how ethnic differences should guide a diverse agenda.
Children in a private school have higher scores than other groups; this is especially true for girls compared to any other group. In contrast, children from indigenous schools and rural environments have the lowest scores. Most of the girls studying in public schools live in the Capital City of the State; their parents have more economical resources than the other groups. According to the National Council for the Evaluation of Social Development Policies (CONEVAL), data from 2018 indicated that the State of Hidalgo is on 
the list of the ten poorest states in Mexico ${ }^{18}$. From a total population of $(2,980,532), 43.8 \%$ is on a poverty strata level, and $6.1 \%$ is in extreme poverty conditions. Hidalgo is also the fifth state with more indigenous populations in the country $(26,3 \% \text { from total population })^{19}$. This poverty and inequality in this state is reflected in schools. Children from indigenous communities have a poorest physical and mental development. Compared to the national problem of overweight and obesity in children, Hidalgo has undernutrition and poor access to health food among children from marginalized communities ${ }^{20}$.

Conventionally, research has been focused on indigenous population; nevertheless, rural populations have the same priority with children at school age, undernutrition and poor access to mental and physical health. One of the contributions of this study was to point out this risk population. They are not considered indigenous populations but they have the same risks than this neglected population in the State. It has been reported that Mexican school children from households with food insecurity have a lower consumption of fruits, vegetables and protein-rich foods, and a high consumption of refined grains, which affects their nutritional status; specially children from indigenous and rural environments ${ }^{16,21}$.

On the other hand, girls from private schools, have a stronger association with $\mathrm{MBMI}$ than other girls and boys. This association is related to the presence of higher scores in ZBFA in girls. Access to more economic resources and more calorie intake can be one of the reasons of this increase. Even when boys and girls from private schools have a greater association with MBMI. This result has more implications in diet, and increases the knowledge about mother-children relationship 4 .

It was expected to find similar differences between MBMI among schools; nonetheless, there are no differences between them. This homogenous MBMI can be explained by the widespread overweight and obesity in adults from rural and urban environments and across socio-economic strata in Mexico ${ }^{16}$. Research requires other maternal characteristics (e.g.: educational level, employment status), children environment (school infrastructure, poverty), household (food security) and other anthropometric measurements should be taken into account for better predictions ${ }^{22}$. In addition, psychological aspects such as mother's body image dissatisfaction can have an influence on children's overweight and obesity.

Furthermore, other studies reported important differences in preferences and type of physical activity carried out by school children in private and public schools, as well as the infrastructure resources for recreation and sports available in these schools $^{23}$. Children from private schools have more access to infrastructure resources but, at the same time, have more resources for calorie intake compared to other groups. Accordingly, school agendas should not just be to increase the infrastructure resources, it is equally important to give diet recommendations according to their population.

\section{$\longrightarrow$ CONCLUSIONS}

It was found evidence of a low relationship between Maternal Body Mass Index and Child Body Mass Index. This relationship was stronger when the type of school was added as a covariate. The evidence revealed differences between the environment of rural and urban schools, between mestizo populations and indigenous groups. Intervention programs should take into account the differences between the school environments according to the context. Special attention should be paid to children of indigenous schools and marginalized rural Mexican schools, to reduce the gaps in their condition of malnutrition and improve their life quality.

\section{FUNDING}

The funding come from the Government of the State of Hidalgo through the PENUTEH Project and the Universidad Nacional Autónoma de México PAPIME Project PE306418.

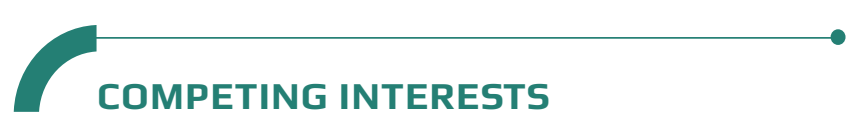

Authors state that there are no conflicts of interest in preparing the manuscript.

\section{REFERENCES}

(1) Mitchell EA, Stewart AW, Braithwaite I, Hancox RJ, Murphy R, Wall C, Beasley R. Birth weight and subsequent body mass index in children: an international cross-sectional study. Pediatr Obes. 2017; 12(4): 280-85. 
(2) Instituto Nacional de Salud Pública. Encuesta Nacional de Salud y Nutrición de Medio Camino 2016 (ENSANUT 2016). Informe final de resultados. Cuernavaca, México: Instituto Nacional de Salud Pública; 2016. Available: https://ensanut. insp.mx/encuestas/ensanut2016/informes.php

(3) Vassallo P, Azzolina D, Soriani N, Gregori D, Lorenzoni G. Association between simple anthropometric measures in children of different ethnicities: Results from the OBEY-AD study. Arch Latinoam Nutr. 2017; 67(1): 98-107.

(4) Veldhuis J, te Poel F, Pepping R, Konijn EA, Spekman MLC. "Skinny is prettier and normal: I want to be normal"-Perceived body image of non-Western ethnic minority children in the Netherlands. Body Image. 2017; 20: 74-86.

(5) Datar A, Nicosia N, Shier V. Parent perceptions of neighborhood safety and children's physical activity, sedentary behavior, and obesity: Evidence from a national longitudinal study. Am J Epidemiol. 2013; 177(10): 1065-73.

(6) O'Hara JK, Haynes-Maslow L. Examining the Association Between School Vending Machines and Children's Body Mass Index by Socioeconomic Status. J Nutr Educ Behav. 2015; 47(6): 526-31.

(7) Tigga PL, Sen J. Maternal Body Mass Index Is Strongly Associated with Children-Scores for Height and BMI. J of Anthropoly. 2016: 1-10.

(8) Ackerson LK, Smith GD, John NA. With Child Mortality, Anthropometric Failure. Am Med Assoc. 2009; 301(16): 1691-701.

(9) Mohammad K, Kassab M, Gamble J, Creedy DK, Foster J. Factors associated with birth weight inequalities in Jordan. Int Nurs Rev. 2014; 61(3): 435-40.

(10) Petrou S, Kupek E. Poverty and childhood undernutrition in developing countries: A multi-national cohort study. Soc Sci Med. 2010; 71(7): 1366-73.

(11) Siddiqui MZ, Donato R. Undernutrition among adults in India: The significance of individual-level and contextual factors impacting on the likelihood of underweight across subpopulations. Public Health Nutr. 2017; 20(1): 130-41.

(12) Rachmi CN, Agho KE, Li M, and Baur LA. Stunting, underweight and overweight in children aged 2.0-4.9 years in Indonesia: Prevalence trends and associated risk factors. PLoS One. 2016; 11(5): 1-18.
(13) Secretaría de Educación Pública. Educación Primaria, 2018 Available: https://www.gob.mx/sep

(14) Secreataría de Educación Pública. Consejo Nacional de Fomento Educativo Conafe, 2018. Available: https://gobierno. com.mx/conafe.html

(15) Gobierno del Estado de Hidalgo. Avaible: http://www.hidalgo. gob.mx

(16) Contreras-Manzano A, Villalpando S, Robledo-Pérez R. Vitamin $D$ status by sociodemographic factors and body mass index in Mexican women at reproductive age. Salud Pública Mex. 2017 59(5): 518-25.

(17) De Onis M, Onyango AW, Borghi E, Siyam A, Nishida C, Siekmann J. Development of a WHO growth reference for school-aged children and adolescents. Bull World Heal Organ. 2007; 58(10): 812-19.

(18) CONEVAL, 10 años de medición de pobreza en México, avances y retos de política social Hidalgo. Comunicad de prensa no. 10. Available: https://www.coneval.org.mx/coordinacion/ entidades/Documents/Comunicados_Pobreza_2018/ COMUNICADO_MEDICION_POBREZA_2018_HIDALGO.pdf

(19) Chávez MC, Mádrigal H, Villa AR, Guarneros N. Alta prevalencia de desnutrición en la población infantil indígena mexicana: Encuesta Nacional de Nutrición 1999. Rev Esp Salud Pública. 2003; 77(2): 245-55.

(20) Malina RM, Little BB, Lanceta J, Peña Reyes ME, Bali Chávez G. Geographic variation in the growth status of indigenous school children and youth in Mexico. Am J Phys Anthropol. 2018; 167(4): 791-803.

(21) Rodríguez LA, Mundo-Rosas V, Méndez-Gómez-Humarán I, Pérez-Escamilla R, Shamah-Levy T. Dietary quality and household food insecurity among Mexican children and adolescents. Matern Child Nutr. 2017; 13(4).

(22) Espinosa AM. Maternal employment and Mexican school-age children overweight in 2012: the importance of households features. Bol Med Hosp Infant Mex. 2018; 75(2): 104-112.

(23) Galván M, Monroy-Campos A, López-Rodríguez G, GonzálezUnzaga M, Olivo D, Hernández-Cabrera J, et al. Physical activity in Mexican urban school children: Differences by nutritional status and school type. Glo Adv Res J Med Med Sci. 2017; 6(12): 362-368. 